\title{
APLIKASI OLEOGEL DENGAN OLEOGELATOR LEMAK KAKAO PADA PEMBUATAN COKELAT
}

\author{
Application of Oleogel with Cocoa Butter Oleogelator for Chocolate Making
}

\author{
Sitti Ramlah, Eky Yenita Ristanti, Endang Sri Rejeki, Justus E. Loppies, dan Dyah Wuri Asriati \\ Balai Besar Industri Hasil Perkebunan \\ Jl.Prof.Dr. Abdurahman Basalamah No. 28, Makassar 90231 \\ Email: st.ramlah.bbihp@gmail.com
}

\begin{abstract}
Oleogel is lipophilic fat and solid mixture, which solid fat material (oleogelator) with lower concentration (<10\%) can absorbed by forming an oleogator network in bulk oil. Oleogel is used to produce fat with desirable structural properties. The aims of this study is to apply oleogel from palm oil and soybean oil with cocoa butter oleogelator in chocolate making. This research was carried out in 2 stages, namely oleogelmaking and chocolatemaking. Chocolatemaking is made with 10 formulas namely F1-F10, where F1-F8 using oleogel as fat replacer, while F9 and F10 using Cocoa Butter Substitute (CBS) as fat replacer as control. The content of water, sugar, fat, protein, metal, and organoleptic test was analyzed. The results showed that oleogel from palm oil and soybean oil with cocoa butter oleogelator can be used as fat replacer in chocolate making. Chocolate that uses oleogel fat has quality characteristics namely; water content of 1.04-1.94\%, sugar content of $35.61-42.19 \%$, fat content of $40.01-48.25 \%$, protein content of $9.64-11.03 \%$, metal content of As $(<0.007 \mathrm{ppm}), \mathrm{Cd}(<0.08$ ppm), $\mathrm{Hg}(<0.003 \mathrm{ppm})$.
\end{abstract}

Keywords: chocolate, soybean oil, palm oil, oleogel.

Abstrak: Oleogel didefinisikan sebagai lemak lipofilik dan campuran padat, dimana material lemak padat (oleogelator) dengan konsentrasi yang lebih rendah $(<10 \%)$ dapat menjerap dengan cara membentuk jejaring oleogator pada minyak curah. Oleogel digunakan untuk menghasilkan lemak dengan sifat struktur yang diinginkan. Penelitian ini bertujuan untuk mengaplikasikan oleogel dari minyak sawit dan minyak kedelai dengan oleogelator lemak kakao pada pembuatan cokelat. Penelitian ini dilakukan 2 tahap yaitu pembuatan oleogel dan pembuatan cokelat. Pembuatan cokelat dibuat dengan 10 formula yaitu F1-F10, dimana F1-F8 menggunakan oleogel sebagai pengganti lemak, sedangkan F9 dan F10 merupakan pembanding dimana pengganti lemak yang digunakan adalah Cocoa Butter Substitute (CBS). Parameter uji adalah kadar air, gula, lemak, protein, kandungan logam, dan uji organoleptik. Hasil penelitian menunjukkan bahwa oleogel dari minyak sawit dan minyak kedelai dengan oleogelator lemak kakao dapat digunakan sebagai pengganti lemak pada pembuatan cokelat. Cokelat dengan penggunaan lemak oleogel mempunyai karakteristik mutu yaitu; kadar air 1,04-1,94 \%, gula 35,61$42,19 \%$, lemak 40,01-48,25\%, protein 9,64-11,03\%, kadar logam As (<0,007 ppm), Cd (<0,08 ppm), $\mathrm{Hg}(<0,003 \mathrm{ppm})$.

Kata kunci : cokelat, minyak kedelai, minyak sawit, oleogel.

\section{PENDAHULUAN}

Industri makanan dan minuman Indonesia sedang tumbuh pesat dengan omset 400 triliun rupiah (sekitar 30,5 miliar USD) pada kuartal pertama 2016. Menurut Gabungan Asosiasi Pengusaha Makanan dan Minuman Indonesia (GAPMMI), pertumbuhan sektor makanan dan minuman pada kuartal pertama 2016 berada pada kisaran 8-9\%. Akan tetapi, industri ini mengalami tantangan dalam hal meningkatnya kebutuhan akan ketersediaan bahan baku serta upah buruh (Omron,2016).
Bahan baku industri makanan dan minuman olahan di dalam negeri masih sangat bergantung pada pasokan impor, bahkan ada yang harus mengimpor bahan baku hingga 100\%. Ketergantungan terhadap impor tersebut disebabkan karena beberapa faktor, diantaranya pasokan dari dalam negeri yang belum memenuhi ketentuan baik dari sisi standar, jenis, spesifikasi maupun skala ekonomi. Selain itu, data mengenai jumlah pasokan bahan baku dengan data kebutuhan industri sering tidak sinkron (Ningsih, 2016). 
Minyak dan lemak digunakan secara meluas pada industri makanan dan minuman untuk memperbaiki nutrisi dan mutu produk. Lemak padat diproduksi dari minyak melalui proses hidrogenasi, interesterifikasi, dan fraksinasi. Lemak padat banyak digunakan pada berbagai makanan olahan untuk memperbaiki maupun memodifikasi cita rasa dan tekstur, mengembangkan adonan, mengemulsi, memindahkan panas pada proses penggorengan, mencegah penggumpalan serta memberi rasa kenyang. Sayangnya, konsumsi lemak jenuh yang berlebih dapat meningkatkan resiko terserang penyakit kardiovaskuler, kegemukan, dan obesitas (PehlivanoĞlu et al., 2016).

Pada pembuatan cokelat sering digunakan lemak Cocoa Butter Substitute (CBS) untuk menggantikan lemak kakao. CBS memiliki karakter fisik yang mirip dengan lemak kakao. Cokelat yang dibuat dengan lemak Cocoa Butter Substitute (CBS) juga dapat digunakan langsung tanpa harus melalui proses tempering. Cokelat yang dibuat dengan CBS akan lebih cepat lumer di mulut. Sifat ini sangat mirip dengan cokelat yang dibuat dengan Cocoa Butter (Anonim, 2019a).

Selain penggunaan CBS, sekarang ini diupayakan untuk mencari alternatif pengganti penggunaan lemak padat. Salah satu perkembangan teknologi dalam industri pangan untuk mengurangi penggunaan lemak padat adalah dengan menggunakan oleogel. Oleogel dapat didefinisikan sebagai lemak lipofilik dan campuran padat, dimana material lemak padat (oleogator) dengan konsentrasi yang lebih rendah $(<10 \%)$ dapat menyerap globula lemak atau minyak dengan cara membentuk jejaring oleogator pada minyak curah. Oleogator dapat digolongkan menjadi dua, yakni sistem self-assembly dan sistem partikel kristal (Samuditha et al., 2011).

Oleogelasi atau proses pembentukan oleogel, meliputi gelasi dari minyak dengan bantuan gelator tunggal atau kombinasi sinergis dari beberapa molekul gelator yang berbeda. Oleogelasi menjadi solusi untuk menjawab tantangan kebutuhan teknologi untuk mengubah struktur minyak pangan yang ada. Organogel merupakan cikal bakal oleogel. Organogel konvensional menggunakan pelarut organik dan pada umumnya digunakan pada industri kimia, sedangkan oleogel menggunakan lemak alami yang aman dikonsumsi (edible). Beberapa oleogel yang telah dibuat diantaranya menggunakan oleogator dari lilin candellila (candellila wax, CLX) (ToroVazquez et al, 2007) dan lilin mata beras (rice bran wax) (Kodali, 2009; Dassanayake, 2009).

Pada industri pangan olahan, penggunaan minyak dan lemak semakin meningkat, baik sebagai komponen utama maupun sebagai pengikat untuk memberikan tekstur yang diinginkan. Dengan semakin tingginya konsumsi makanan olahan, maka konsumsi minyak dan lemak, terutama minyak dan lemak jenuh, juga semakin tinggi. Minyak dan lemak jenuh, memicu masalah kesehatan seperti kolesterol tinggi yang dapat memicu penyakit stroke dan jantung. Oleh karena itu, produsen makanan mulai menaruh perhatian terhadap bahanbahan yang dapat menggantikan peranan minyak dan lemak jenuh pada makanan olahan tanpa merusak tekstur dan sifat fisik yang diharapkan. Oleogelasi merupakan proses untuk menata struktur minyak dan lemak sehingga ketika diaplikasikan pada produk makanan olahan dapat memperbaiki karakteristik fungsional seperti tekstur, kerenyahan, tampilan dan stabilitas. Selain itu, proses ini juga tidak memerlukan biaya yang mahal dan tidak berdampak negatif terhadap kesehatan (Ristanti et al., 2018).

Oleogel pada awalnya dikembangkan untuk penggunaan pada bidang farmasi dan kosmetik. Namun, oleogel mulai dikembangkan untuk digunakan pada pembuatan makanan karena berdasarkan beberapa studi (Van, 2014; DavidovichPinhas, 2016) memiliki potensi untuk mengurangi penggunaan lemak jenuh yang tidak baik bagi kesehatan. 
Industri makanan saat ini mulai meninggalkan penggunaan lemak trans pada berbagai produk pangan. Kesehatan dan kesejahteraan menjadi fokus global sehingga menjadi tantangan tersendiri bagi industri makanan untuk menghasilkan produk yang lebih rendah kalori, rendah lemak serta rendah lemak jenuh, tetapi masih memiliki rasa yang enak.Untuk itu, teknologi penataan ulang lemak kini banyak dikembangkan untuk memperbaiki mutu shortening yang ada di pasaran.

Tujuan penelitian ini adalah untuk mengaplikasikan oleogel dari minyak sawit dan minyak kedelai dengan lemak kakao sebagai oleogelator pada pembuatan cokelat.

\section{METODOLOGI}

\section{Bahan dan Alat}

Bahan baku yang digunakan pada penelitian ini adalah oleogel dari minyak sawit, oleogel dari minyak kedelai, gula sukrosa, CBS, lesitin, vanili, pasta kakao, dan bubuk kakao. Sedangkan alat yang digunakan adalah stirer, counching (Universal Counching), melter, dan cetakan cokelat.

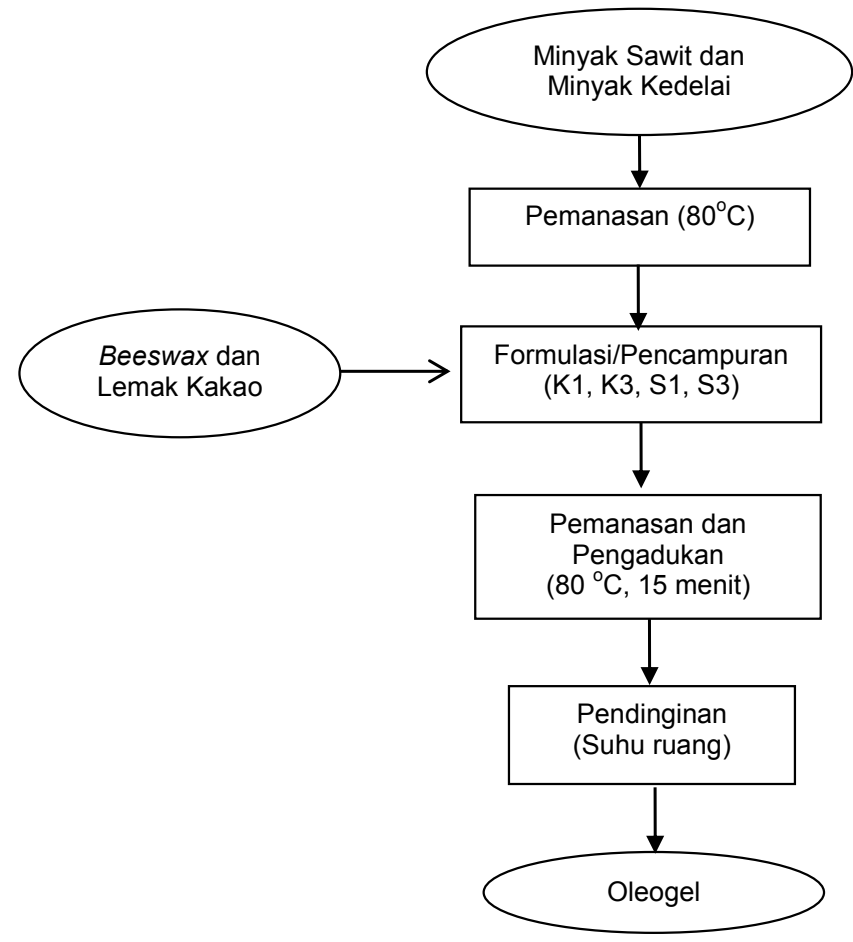

Gambar 1. Proses Pembuatan Oleogel dengan Oleogelator Lemak Kakao

\section{Metode Penelitian}

Penelitian ini dilakukan dengan beberapa tahap, yaitu tahap pembuatan oleogel dari minyak sawit dan minyak kedelei dengan oleogator lemak kakao dengan mengacu pada hasil penelitian Ristanti et al. (2017), tahap pembuatan cokelat mengacu pada hasil penelitian Ramlah (2016) dengan pengembangan formula dengan bahan baku lemak oleogel, tahap analisa kimia, dan uji organoleptik cokelat yang dihasilkan.

\section{Pembuatan Oleogel dan Cokelat}

Pembuatan oleogel dari minyak sawit dan minyak kedelai dengan oleogator lemak kakao mengacu pada hasil penelitian Ristanti et al. (2017) dengan formula (Tabel 1) dan proses pembuatan seperti pada Flowchart Proses Pembuatan Oleogel (Gambar 1). 
Tabel 1. Formulasi Oleogel

\begin{tabular}{cccc}
\hline Formula & Minyak Sawit $(\%)$ & Beeswax $(\%)$ & Lemak Kakao $(\%)$ \\
\hline S1 & 90 & 9 & 1 \\
S3 & 90 & 7 & 3 \\
\hline Formula & Minyak Kedelai $(\%)$ & Beeswax $(\%)$ & Lemak Kakao $(\%)$ \\
\hline K1 & 90 & 9 & 1 \\
K3 & 90 & 7 & 3 \\
\hline
\end{tabular}

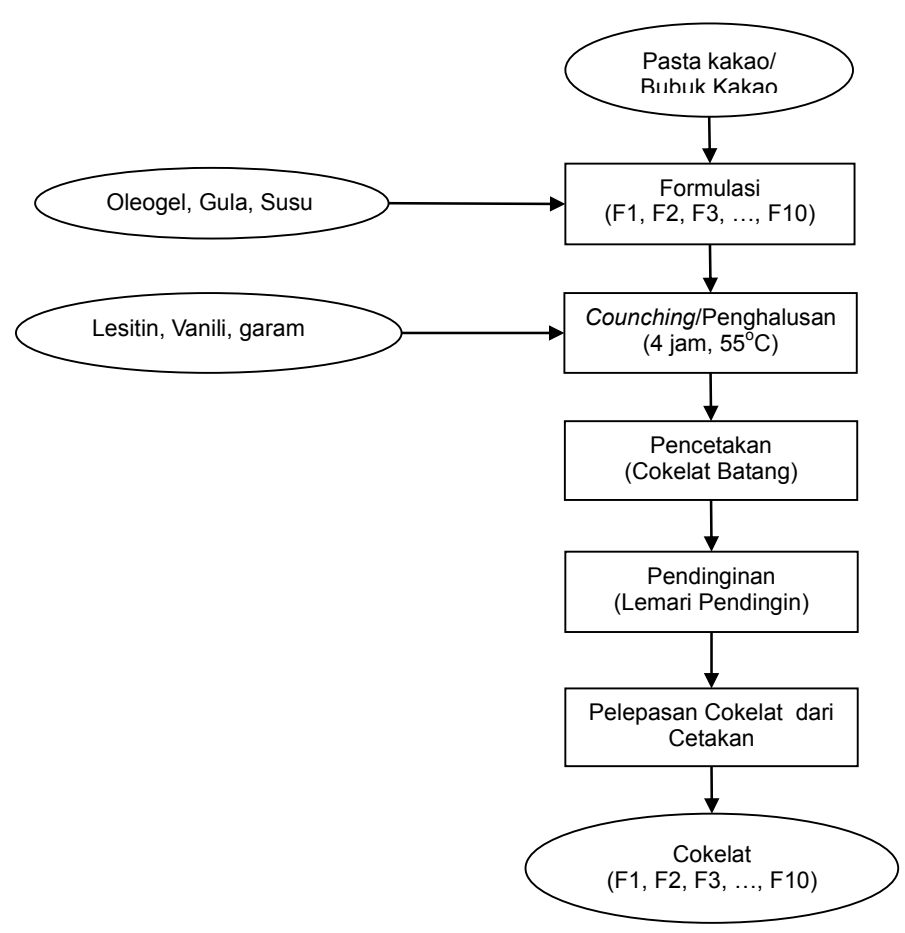

Gambar 2. Proses Pembuatan Cokelat

Tabel 2. Formulasi Cokelat dengan Oleogel

\begin{tabular}{|c|c|c|c|c|c|c|c|c|c|c|c|}
\hline No. & $\begin{array}{l}\text { Bahan } \\
\text { Baku }\end{array}$ & $\begin{array}{l}\mathrm{F}(\mathrm{PS} 1) \\
\mathrm{F} 1\end{array}$ & $\begin{array}{l}F(P S 3) \\
F 2\end{array}$ & $\begin{array}{l}\text { F(PK1) } \\
\text { F3 }\end{array}$ & $\begin{array}{l}\mathrm{F}(\mathrm{PK} 3) \\
\mathrm{F} 4\end{array}$ & $\begin{array}{l}\mathrm{F}(\mathrm{BS} 1) \\
\mathrm{F} 5\end{array}$ & $\begin{array}{l}F(B S 3) \\
F 6\end{array}$ & $\begin{array}{l}\mathrm{F}(\mathrm{BK} 1) \\
\mathrm{F} 7\end{array}$ & $\begin{array}{l}F(B K 3) \\
F 8\end{array}$ & $\begin{array}{l}F(P C B S) \\
\text { F9 }\end{array}$ & $\begin{array}{l}F(B C B S) \\
\text { F10 }\end{array}$ \\
\hline 1. & $\begin{array}{l}\text { Pasta } \\
\text { Kakao } \\
(\mathrm{kg})\end{array}$ & 2 & 2 & 2 & 2 & - & - & - & - & 2 & - \\
\hline 2. & $\begin{array}{l}\text { Bubuk } \\
\text { Kakao } \\
\text { (kg }\end{array}$ & - & - & - & - & 2 & 2 & 2 & 2 & - & 2 \\
\hline 3. & $\begin{array}{l}\text { Oleogel } \\
\text { S1 (kg) }\end{array}$ & 2 & - & - & - & 2 & - & - & - & - & - \\
\hline 4. & $\begin{array}{l}\text { Oleogel } \\
\text { S3 (kg) }\end{array}$ & - & 2 & - & - & - & 2 & - & - & - & - \\
\hline 5. & $\begin{array}{l}\text { Oleogel } \\
\text { K1 (kg) }\end{array}$ & - & - & 2 & - & - & - & 2 & - & - & - \\
\hline 6. & $\begin{array}{l}\text { Oleogel } \\
\text { K3 (kg) }\end{array}$ & - & - & - & 2 & - & - & - & 2 & - & - \\
\hline 7. & CBS & - & - & - & - & - & - & - & & 2 & 2 \\
\hline 8. & $\begin{array}{l}\text { Gula } \\
\text { Sukrosa } \\
\text { (kg) }\end{array}$ & 2 & 2 & 2 & 2 & 2 & 2 & 2 & 2 & 2 & 2 \\
\hline
\end{tabular}




\begin{tabular}{|c|c|c|c|c|c|c|c|c|c|c|c|}
\hline 9. & $\begin{array}{l}\text { Susu } \\
\text { Bubuk } \\
\text { (kg) }\end{array}$ & 1,6 & 1,6 & 1,6 & 1,6 & 1,6 & 1,6 & 1,6 & 1,6 & 1,6 & 1,6 \\
\hline 10 & $\begin{array}{l}\text { Lesitin } \\
\text { (gr) }\end{array}$ & 30 & 30 & 30 & 30 & 30 & 30 & 30 & 30 & 30 & 30 \\
\hline 11. & $\begin{array}{l}\text { Vanili } \\
\text { (gr) }\end{array}$ & 8 & 8 & 8 & 8 & 8 & 8 & 8 & 8 & 8 & 8 \\
\hline 12. & $\begin{array}{l}\text { Garam } \\
\text { (gr) }\end{array}$ & 4 & 4 & 4 & 4 & 4 & 4 & 4 & 4 & 4 & 4 \\
\hline
\end{tabular}

\section{Parameter Uji}

Parameter uji yang digunakan pada penelitian ini adalah kadar air (SNI 01-28911992), kadar gula (SNI 01-2892-1992), kadar lemak (SNI 3748:2009), kandungan logam (AAS), uji organoleptik terhadap tekstur, warna, aroma, dan rasa dengan menggunakan skala hedonik 1 hingga 5 dengan jumlah panelis 20 orang ( 1 = sangat tidak suka; 2 = tidak suka; 3 = agak suka; 4 = suka; 5 = sangat suka).

\section{HASIL DAN PEMBAHASAN}

\section{Kadar Air}

Air merupakan komponen penting dalam bahan makanan karena air dapat mempengaruhi penampakan, tekstur, tingkat kerenyahan produk akhir serta cita rasa makanan. Keawetan dari suatu produk berhubungan erat dengan kadar airnya (Winarno, 2004).

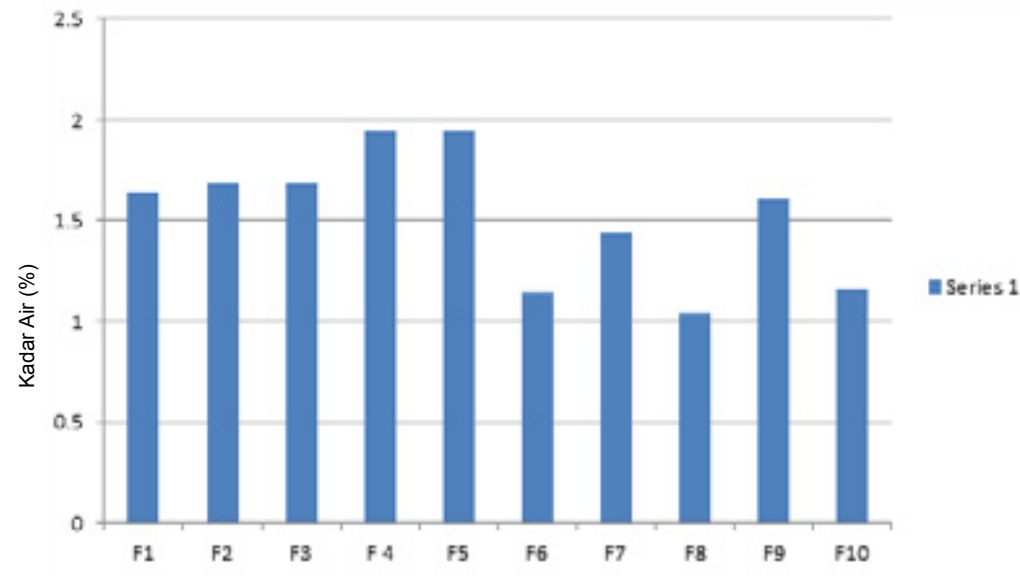

Gambar 3. Histogram Kadar Air Cokelat

Hasil analisa kimia produk cokelat yang dihasilkan (F1 hingga F10), mempunyai kadar air berkisar 1,04\% hingga 1,94\% (Gambar 3). Secara keseluruhan semua formula menghasilkan kadar air yang rendah dan tidak berbeda jauh antara satu formula dengan formula lainnya. Hal ini disebabkan karena semua formula diolah dengan tahapan pengolahan yang sama (suhu dan lama penghalusan). Namun jika ditinjau dari bahan baku yang digunakan antara pasta cokelat (F1, F2, F3, F4, dan F9) dan bubuk cokelat (F5, F6, F7, F8, dan F10), maka produk cokelat yang diolah dari bahan baku bubuk kakao cenderung menghasilkan produk cokelat dengan kadar air yang lebih rendah dibanding dengan cokelat yang diolah dari pasta kakao. Hal ini disebabkan bubuk kakao yang digunakan mempunyai kadar air yang lebih rendah dibanding kadar air pasta kakao.

\section{Kadar Gula}

Gula atau sukrosa memiliki peranan penting dalam pengolahan pangan karena 
fungsinyayang beranekaragam, yaitu sebagai pemanis, pembentuk tekstur, pengawet, pembentuk cita rasa, sebagai substrat bagi mikroba dalam proses fermentasi, bahan pengisi, dan pelarut.

Sukrosa merupakan senyawa kimia yang termasuk dalam golongan karbohidrat, memiliki rasa manis, berwarna putih, bersifat anhydrous dan kelarutannya dalam air mencapai $67,7 \%$ pada suhu $20{ }^{\circ} \mathrm{C}(\mathrm{w} / \mathrm{w})$. Komponen terbesar yang digunakan dalam industri konfeksioneri adalah gula pasir (sukrosa).

Hasil penelitian (Gambar 4) menunjukkan bahwa produk cokelat yang dihasilkan mempunyai kadar gula berkisar $35,61 \%$ hingga 43,28\% (F1 s/d F10). Cokelat yang dihasilkan dari setiap formula mempunyai kandungan gula yang hampir sama. Hal ini disebabkan oleh penggunaan jumlah gula yang sama pada proses pengolahan cokelat untuk semua formula.
Penggunaan oleogel baik oleogel dari minyak sawit maupun oleogel dari minyak kedelai sebagai pengganti lemak kakao pada pembuatan cokelat dan bahan baku lainnya seperti susu, pasta, dan bubuk kakao tidak memberikan pengaruh yang besar terhadap kandungan gula cokelat yang dihasilkan.

Gula berfungsi membantu pembentukan tekstur, memberi flavor melalui reaksi pencoklatan, dan memberi rasa manis. Selain itu, apabila gula ditambahkan ke dalam bahan makanan pada konsentrasi cukup tinggi (paling sedikit $40 \%$ padatan terlarut), sebagian air yang ada menjadi tidak tersedia untuk pertumbuhan mikrobiologi dan Aw dari bahan pangan berkurang. Daya larut yang tinggi dari gula dan kemampuannya mengurangi keseimbangan relatif dan mengikat air adalah sifat-sifat yang menyebabkan gula dipakai dalam proses pengawetan pangan (Buckle et al., 1987).

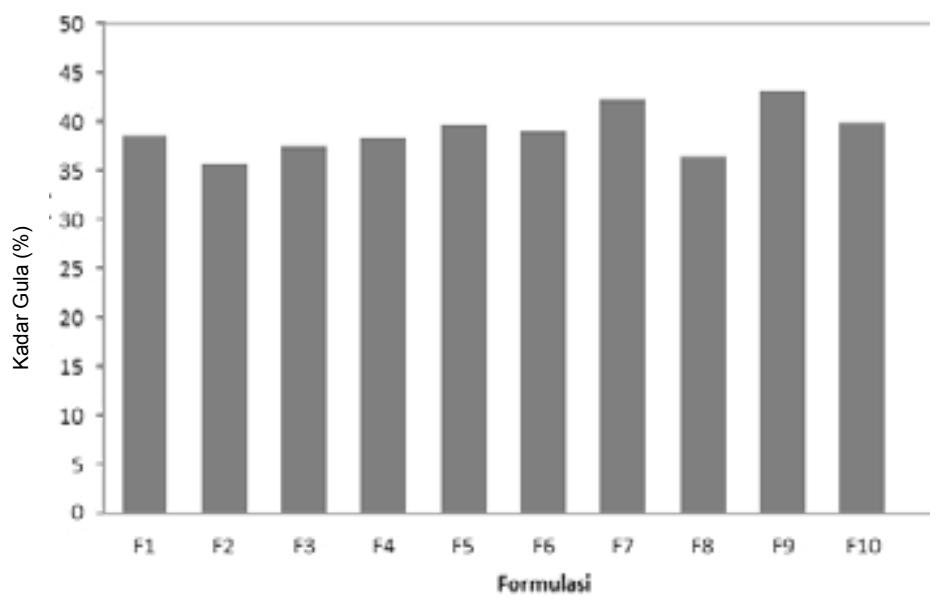

Gambar 4. Histogram Kadar Gula Cokelat

\section{Kadar Lemak}

Lemak adalah campuran trigliserida dalam bentuk padat dan terdiri dari suatu fase padat dan fase cair (Buckle et al, 1987). Dalam pengolahan produk pangan, umumnya penggunaan lemak ditujukan untuk menambah cita rasa.

Kadar lemak cokelat yang dihasilkan sangat dipengaruhi oleh kandungan lemak dari bahan baku yang digunakan seperti pasta kakao atau bubuk kakao, lemak kakao/lemak lainnya, susu, dan lain-lain.

F1 hingga F10 mengandung lemak berkisar 40,01\% hingga 50,95\% (Gambar 5). Kandungan lemak pada suatu produk dipengaruhi oleh bahan baku yang digunakan. Pada penelitian ini, kadar lemak cokelat yang dihasilkan dipengaruhi oleh bahan baku oleogel yang digunakan sebagai pengganti lemak kakao. Selain itu, juga dipengaruhi oleh bahan baku pasta kakao dan bubuk 
kakao. Namun, jika dibandingkan antara satu formula dengan formula lainnya, maka penggunaan oleogel tidak mempengaruhi kadar lemak cokelat yang dihasilkan karena setiap formula menggunakan volume atau jumlah oleogel yang sama. Namun, jika dilihat dari penggunaan bahan baku bubuk cokelat dan pasta kakao, maka produk cokelat yang diolah dari bahan baku bubuk kakao mempunyai kadar lemak yang lebih rendah dibanding dengan cokelat yang diolah dari pasta kakao. Bubuk kakao mempunyai kadar lemak yang lebih rendah dari pasta kakao karena bubuk kakao merupakan produk yang dihasilkan dari proses pengepresan pasta kakao sehingga lemak kakao yang terdapat dalam pasta kakao terpisah atau keluar dari pasta dan diperoleh cake yang selanjutnya dijadikan bubuk kakao. Cokelat dengan formula F1-F4 dan F9 menggunakan bahan baku pasta kakao, sedangkan F5-F8 dan F10 menggunakan bahan baku bubuk kakao.

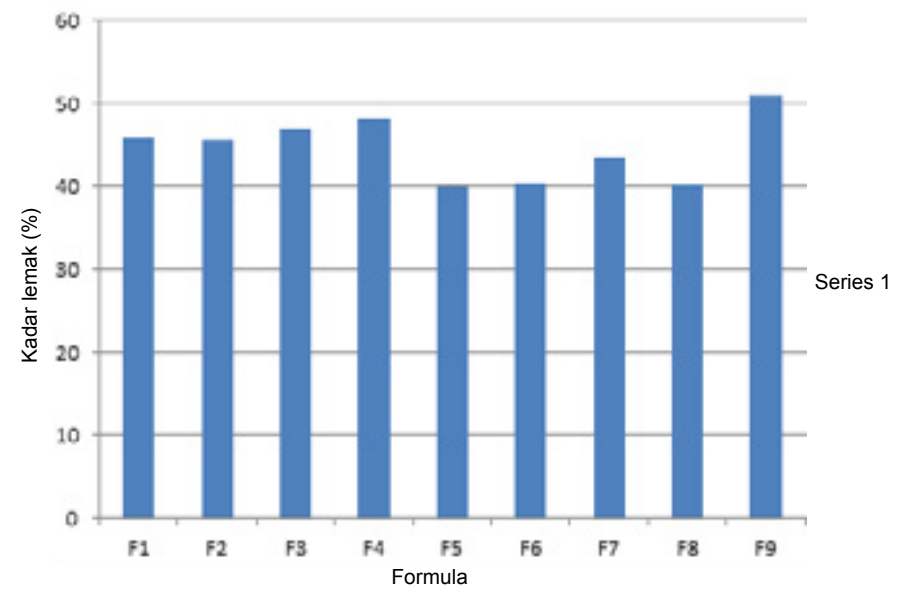

Gambar 5. Histogram Kadar Lemak Cokelat

Hasil penelitian menunjukkan bahwa produk cokelat yang dihasilkan dari formula F1. Lemak merupakan unsur yang penting dalam cokelat, sama halnya seperti gula. Keduanya memberikan pengaruh yang sangat berarti untuk rasa dan tekstur, dimana fungsi dari lemak pada pembuatan cokelat yakni untuk memadatkan (Ketaren, 1986). Industri pengolahan cokelat umumnya menggunakan lemak kakao sebagai bahan baku pada proses pembuatannya. Lemak kakao memiliki sifat khas yakni bersifat plastis dan memiliki kandungan lemak padat yang relatif tinggi (Wahyudi et al., 2008). Namun, dalam perkembangan industri pengolahan cokelat sering digunakan jenis lemak lain sebagai pengganti lemak kakao. Menurut Minifie (1999), lemak yang tidak memiliki persamaan dengan lemak kakao tetapi dapat digunakan dengan baik apabila dicampurkan dalam jumlah kecil pada lemak kakao atau cokelat dapat disebut sebagai pengganti lemak kakao. Lemak ini dapat diproduksi dari minyak kelapa, kelapa inti sawit serta minyak kacang .

\section{Kadar Protein}

Protein sangat penting bagi tubuh, karena berfungsi sebagai bahan bakar dalam tubuh juga berfungsi sebagai zat pembangun dan pengatur. Kandungan protein di dalam suatu produk pangan akan menentukan mutu produk pangan itu sendiri. Molekul protein tersusun dari atom karbon (C), hidrogen $(\mathrm{H})$, oksigen $(\mathrm{O})$, dan nitrogen $(\mathrm{N})$. Sebagian besar protein juga mengandung sulfur (S) dan fosfor (P) (Sugiyono, 2004). Protein dalam produk pangan yang dikonsumsi oleh manusia umumnya akan diserap oleh usus dalam bentuk asam amino. Kadang-kadang beberapa asam amino yang merupakan peptida dan molekul-molekul protein kecil dapat juga diserap melalui dinding usus, masuk ke dalam pembuluh darah. Molekul 
protein tersusun dari sejumlah asam amino sebagai bahan dasar yang saling berkaitan satu sama lain (Winarno, 2004). Protein mempunyai mutu yang beraneka ragam tergantung sampai seberapa jauh protein itu dapat menyediakan asam amino essensial dalam jumlah yang memadai (Buckle et al., 1987)

Hasil penelitian menunjukkan bahwa kadar protein dari produk cokelat yang dihasilkan dari formula F1 hingga F10 berkisar $9,64 \%$ hingga $11,03 \%$ (Gambar 6) dimana kandungan protein cokelat dari beberapa formula tidak berbeda jauh antara formula satu dengan formula lainnya seperti antara F2, F4, dan F5. Demikian juga antara F1 dengan F8, serta antara F3, F6, dan F7. Penggunaan lemak oleogel dan CBS tidak memberikan konstribusi yang besar terhadap kandungan protein. Oleogel yang digunakan pada penelitian ini diolah dari minyak kelapa sawit dan minyak kedelai, dan CBS diolah dari minyak kelapa sawit. Di samping oleogel atau CBS, cokelat yang dihasilkan pada penelitian ini menggunakan bahan baku dari pasta kakao, bubuk kakao, dan susu bubuk dengan jumlah yang sama sehingga cokelat yang dihasilkan cenderung mempunyai kandungan protein yang hampir sama pula.

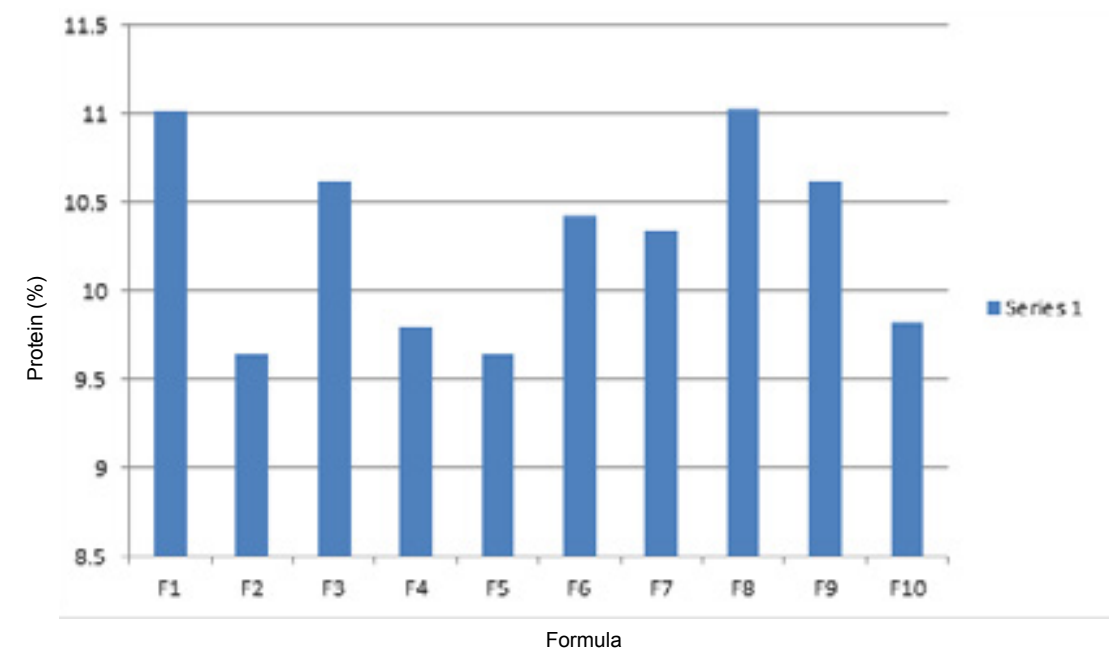

Gambar 6. Histogram Kadar Protein Cokelat

\section{Kandungan Logam Berat}

Logam berat adalah kelompok unsur logam dengan massa jenis lebih besar dari $5 \mathrm{gr} / \mathrm{cm}^{3}$ yang pada tingkat tertentu menjadi bahan beracun dan sangat berbahaya bagi makhluk hidup. Logam berat diantaranya adalah timbal $(\mathrm{Pb})$, merkuri $(\mathrm{Hg})$, arsenik (As), dan cadmium (Cd) (Riadi, 2019). Logam berat umumnya bersifat racun terhadap makhluk hidup walaupun beberapa diantaranya diperlukan dalam jumlah kecil. Melalui beberapa perantara seperti udara, makanan maupun air yang terkontaminasi logam berat, logam tersebut dapat terdistribusi ke tubuh manusia dan sebagian akan terakumulasi. Jika ini berlangsung terus menerus dalam jangka waktu yang lama maka dapat mencapai jumlah yang membahayakan kesehatan manusia (Supriyanto, et al., 2007). 
Tabel 3. Hasil Analisa Kadar Logam Cokelat dengan Oleogel

\begin{tabular}{ccccc}
\hline & & \multicolumn{3}{c}{ Parameter Uji } \\
\cline { 3 - 5 } No. & Formula & $\begin{array}{c}\text { Arsenic }(\text { As }) \\
(\mathrm{mg} / \mathrm{kg})\end{array}$ & $\begin{array}{c}\text { Cadmium(Cd) } \\
(\mathrm{mg} / \mathrm{kg})\end{array}$ & $\begin{array}{c}\text { Mercury }(\mathrm{Hg}) \\
(\mathrm{mg} / \mathrm{kg})\end{array}$ \\
\hline 1. & F1 & $<0,007$ & $<0,08$ & $<0,003$ \\
2. & F2 & $<0,007$ & $<0,08$ & $<0,003$ \\
3. & F3 & $<0,007$ & $<0,08$ & $<0,003$ \\
4. & F4 & $<0,007$ & $<0,08$ & $<0,003$ \\
5. & F5 & $<0,007$ & $<0,08$ & $<0,003$ \\
6. & F6 & $<0,007$ & $<0,08$ & $<0,003$ \\
7. & F7 & $<0,007$ & $<0,08$ & $<0,003$ \\
8. & F8 & $<0,007$ & $<0,08$ & $<0,003$ \\
9. & F9 & $<0,007$ & $<0,08$ & $<0,003$ \\
10. & F10 & $<0,007$ & $<0,08$ & $<0,003$ \\
\hline
\end{tabular}

Dari hasil analisa kandungan logam cokelat dari formula F1 hingga F10 diperoleh kadar As $<0,007 \mathrm{mg} / \mathrm{kg}$, Sn $<1.5 \mathrm{mg} / \mathrm{kg}$, Cd $<0.08 \mathrm{mg} / \mathrm{kg}$, dan $\mathrm{Hg}$ dengan kadar $<0,003$ $\mathrm{mg} / \mathrm{kg}$ (Tabel 3). Rendahnya kandungan logam berat pada cokelat yang dihasilkan dari formula F1 hingga F10 diduga disebabkan oleh bahan baku yang digunakan baik oleogel, CBS, pasta kakao, bubuk kakao, gula sukrosa, dan susu bubuk mengandung kadar logam berat yang rendah pula. Di samping itu, pada proses pengolahan cokelat menggunakan peralatan/wadah yang aman dari bahaya kontaminasi logam berat. Hal ini sesuai yang dikemukakan oleh Iswidodo (2010) bahwa sumber utama kontaminan logam berat sesungguhnya berasal dari udara dan air yang mencemari tanah. Selanjutnya, semua tanaman yang tumbuh di atas tanah yang telah tercemar akan mengakumulasikan logam-logam tersebut pada semua bagian (akar, batang, daun dan buah). Empat sumber utama, yaitu udara yang dihirup saat bernapas, air minum, tanaman (sayuran dan buah-buahan) serta ternak (berupa daging, telur, dan susu). Selanjutnya Anonim (2019b) menyatakan bahwa untuk mengurangi resiko kontaminasi logam berat pada makanan, maka pihak industri seharusnya menggunakan bahan baku yang tidak tercemar dan dalam proses produksi hendaknya menggunakan peralatan, wadah, dan kemasan yang aman dari bahaya kontaminasi logam berat. Jika ditinjau dari Peraturan Badan Pengawas Obat dan Makanan No. 5 Tahun 2018 tentang batas maksimum cemaran logam berat dalam pangan olahan, khususnya pada produk Kembang Gula/Permen dan Cokelat yang menyatakan bahwa batas maksimum logam berat pada produk olahan cokelat adalah arsen (As) sebesar 1,0; cadmium $(\mathrm{Cd})$ sebesar 0,50 dan mercury $(\mathrm{Hg})$ sebesar 0,05 ; maka cokelat yang dihasilkan pada penelitian ini tidak mengandung logam berat dan memenuhi peraturan BPOM (2018) tentang batas maksimum cemaran logam berat dalam pangan, yang berarti aman untuk dikonsumsi.

\section{Uji Organoleptik}

\section{Tekstur}

Salah satu faktor yang sangat penting dalam penentuan kualitas suatu produk termasuk produk cokelat adalah tekstur. Tekstur adalah salah satu bagian dari sifat organoleptik suatu produk. Tekstur merupakan sensasi tekanan yang dapat dirasakan di mulut (waktu digigit, dikunyah, dan ditelan) atau dengan perabaan menggunakan jari (Kartika et al., 1988). 
Penghalusan dan pencampuran bahan yang digunakan serta ada tidaknya pengemulsi yang digunakan pada pembuatan cokelat akan mempengaruhi baik tidaknya tekstur cokelat yang dihasilkan (Minifie, 1999).

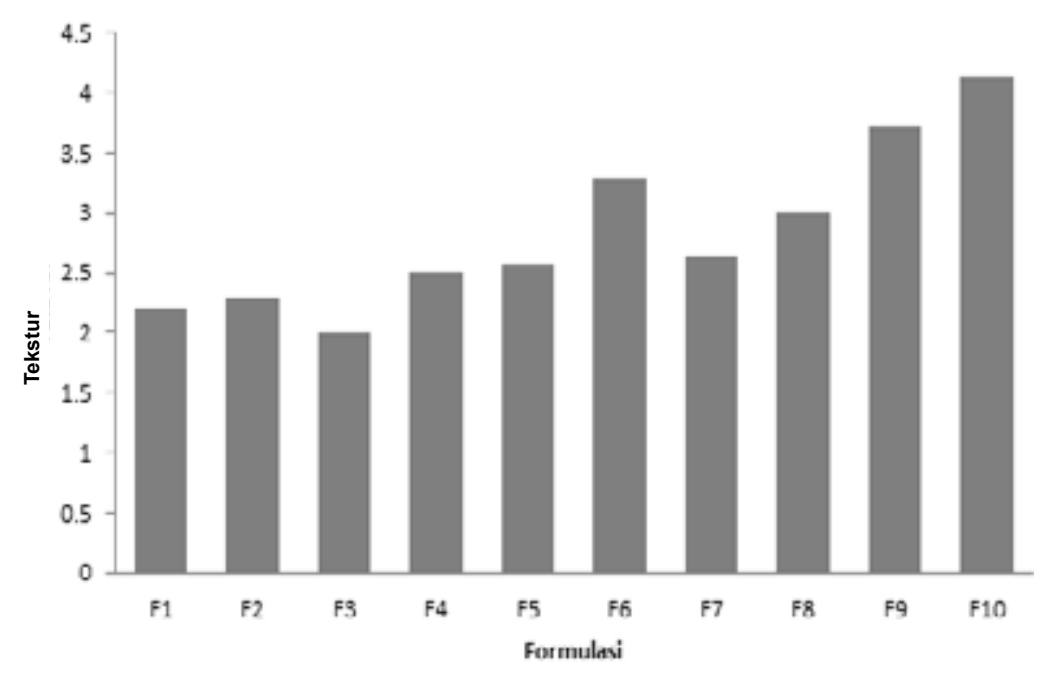

Gambar 7. Histogram Hasil Uji Organoleptik Terhadap Tekstur Cokelat

Hasil uji organoleptik terhadap kehalusan (tekstur) produk yang dihasilkan berkisar 2,21 hingga 3,29 yang berarti tidak suka hingga agak suka (Gambar 7). Cokelat hasil formula F1 hingga F8 mempunyai tekstur yang relatif sama, kecuali pada formula F9 dan F10 dengan nilai 3,71 dan 4,14 yang berarti suka. Hal ini diduga disebabkan mutu oleogel yang digunakan belum maksimal sehingga tingkat kekerasan produk cokelat yang dihasilkan belum sama (agak lembek) dan agak lengket pada cetakan dibanding dengan cokelat yang diolah dengan lemak CBS (F9 dan F10). Oleogel yang digunakan diolah dari minyak sawit dan kedelai dengan oleogelator lemak kakao masih dalam bentuk semi solid, belum dalam bentuk padat seperti halnya CBS. Ristanti et al. (2018) melaporkan bahwa kandungan lemak padat oleogel dari lemak sawit dan minyak kedelai dari berbagai perlakuan mempunyai kandungan lemak padat yang lebih rendah dibandingkan kandungan lemak padat pada CBS. Hal ini disebabkan karena $90 \%$ bahan pembentuk oleogel berada dalam bentuk fraksi minyak berupa asam oleat dan lenolenat, dan 10\% dalam bentuk fraksi padat berupa asam stearat, palmintat, dan laurat. Hal ini akan berpengaruh pada tekstur cokelat yang dihasilkan.

Namun dari segi kehalusan, cokelat yang dihasilkan dari semua formula F1 hingga F10 diperoleh tingkat kehalusan yang relatif sama karena proses pengolahan cokelat menggunakan waktu counching yang sama. Misnawi dan Jinap (2008) menyatakan bahwa pada pengolahan cokelat proses counching merupakan proses yang sangat berpengaruh terhadap cita rasa dan tekstur cokelat. Penghalusan sangat diperlukan untuk menghasilkan tekstur produk cokelat dan kelinciran (smoothness) cokelat saat dimakan. Melalui penghalusan yang baik, fraksi-fraksi padat dalam cokelat akan menyebar rata dalam fraksi cair (lemak) dan potensi aroma, serta cita rasa dan warna khas cokelat timbul. 


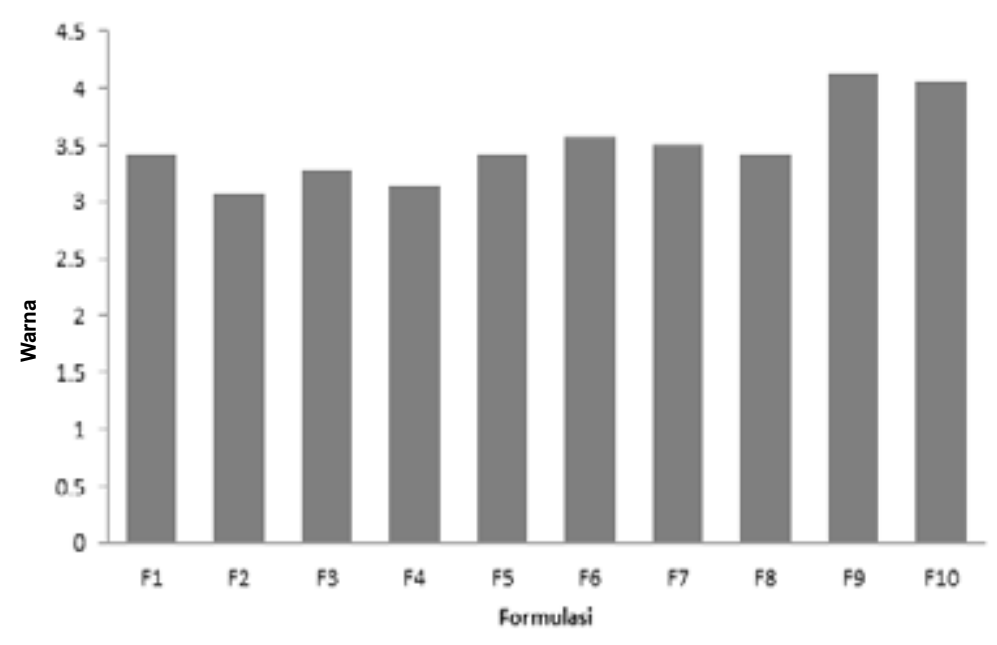

Gambar 8. Histogram Uji Organoleptik Terhadap Warna Cokelat

\section{Warna}

Hasil penilaian organoleptik warna pada produk cokelat pada formula $\mathrm{F} 1$ sampai F8 berkisar 3,07 hingga 3,57 yang berarti rata-rata panelis memberikan respon agak suka hingga suka, sedangkan cokelat hasil formula F9 dan F10 panelis memberikan respon dengan nilai 4 yang berarti suka (Gambar 8). Hal ini disebabkan karena cokelat hasil formula F1 hingga F8 dibuat dengan menggunakan oleogel menghasilkan cokelat yang agak lembek dan cokelat formula F9 dan F10 menggunakan CBS menghasilkan produk cokelat yang lebih keras dan mengkilat sehingga penampakan warna pada permukaan lebih bagus. Oleogel mempunyai tingkat kepadatan atau kekerasan yang lebih rendah dibanding lemak CBS. Tingkat kekerasan lemak memberikan pengaruh terhadap tingkat kekerasan cokelat yang dihasilkan. Hal ini berpengaruh pula terhadap respon panelis terhadap warna cokelat yang dihasilkan pada penelitian ini.

\section{Aroma}

Aroma merupakan salah satu faktor yang menentukan tingkat penerimaan konsumen terhadap produk yang dihasilkan. Menurut Winarno (2004), aroma yang enak dapat menarik perhatian konsumen dan kemungkinan besar memiliki rasa yang enak pula sehingga konsumen lebih cenderung menyukai makanan dari aromanya. Timbulnya aroma makanan disebabkan oleh terbentuknya senyawa yang mudah menguap. Aroma yang dikeluarkan setiap makanan berbeda-beda. Selain itu, cara memasak yang berbeda akan menimbulkan aroma yang berbeda pula (Moehyi, 1992). Aroma khas cokelat tidak saja ditentukan oleh satu komponen, melainkan suatu fungsi dari ratusan komponen penyusunnya. Senyawa-senyawa tersebut terbentuk selama proses penyiapan biji, khususnya saat proses fermentasi dan pengeringan. Selanjutnya pada proses penyangraian senyawa pembentuk cita rasa beraksi satu sama lain sehingga menghasilkan komponen yang mudah menguap dan beraroma khas cokelat (Prasetya, 2009).

Hasil penilaian organoleptik aroma produk cokelat yang dihasilkan dari formula F1 hingga F10 berkisar 2,64 sampai 3,85 yang berarti panelis rata-rata memberikan respon agak suka hingga suka (Gambar 9). Hal ini menunjukkan bahwa penggunaan oleogel (F1 hingga F8) dan CBS (F9 dan F10) tidak mempengaruhi aroma cokelat yang dihasilkan karena oleogel dan CBS yang ditambahkan tidak memiliki aroma.

Penyusun aroma yang ditimbulkan pada cokelat tidak hanya ditentukan oleh 
satu komponen seperti aroma cokelat terbentuk selama penyaringan biji kakao yang merupakan bahan baku dalam pembuatan cocoa powder. Asam amino, peptida, gula pereduksi, dan kuinon merupakan pembentuk cita rasa yang termasuk ke dalam senyawa-senyawa golongan alkohol, eter, furan, tiazol, piron, asam, ester, aldehid, imin, amin, oksazol, pirazin dan pirol (Prasetya, 2009).

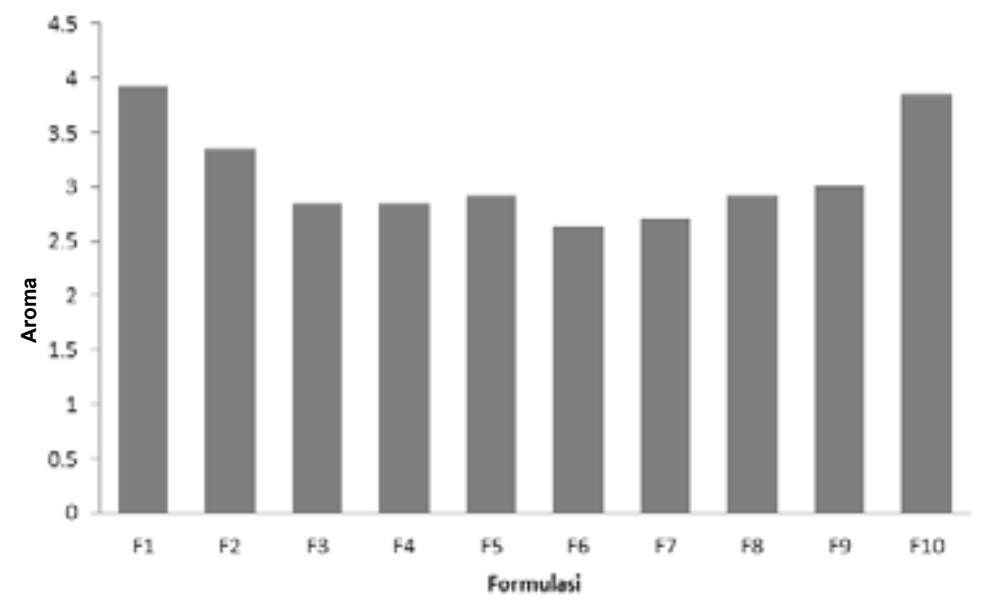

Gambar 9. Histogram Hasil Uji Organoleptik terhadap Aroma Cokelat

\section{Rasa}

Rasa merupakan faktor yang penting dari suatu produk pangan yang dihasilkan. Cita rasa yang timbul tergantung dari senyawa penyusunnya. Umumnya bahan pangan tidak hanya terdiri dari satu macam rasa yang terpadu sehingga menimbulkan cita rasa makanan yang utuh. Perbedaan penilaian panelis terhadap rasa dapat diartikan sebagai penerimaannya terhadap flavour atau cita rasa yang dihasilkan oleh kombinasi bahan yang digunakan (deMan, 1997)

Rasa juga merupakan persepsi dari sel pengecap meliputi rasa asin, manis, asam, dan pahit yang diakibatkan oleh bahan yang mudah terlarut dalam mulut (Meilgard et. al., 1999). Penilaian konsumen terhadap bahan suatu makanan biasanya tergantung pada cita rasa yang ditimbulkan oleh bahan makanan tersebut.

Hasil uji organoleptik terhadap rasa cokelat dari oleogel yang dihasilkan (F1-F8), nilai rata-rata berkisar dari 2,21 hingga 2,86 yang berarti tidak suka hingga agak suka. Hal ini diduga disebabkan karena oleogel yang digunakan masih memberikan rasa asli minyak yang digunakan yaitu minyak sawit dan minyak kedelai. Sedangkan penilaian panelis pada formula $\mathrm{F} 9$ dan F10 sebesar 4.30 (suka) dimana kedua formula ini menggunakan lemak CBS. Rendahnya nilai rasa cokelat $\mathrm{F} 1$ hingga $\mathrm{F} 8$ dibandingkan dengan nilai rasa cokelat F9 dan F10 disebabkan cokelat dari F1 hingga F8 menggunakan lemak oleogel dari minyak sawit dan minyak kedelai, dimana cokelat yang dihasilkan mempunyai rasa minyak sawit atau minyak kedelai yang terasa ditenggorokan sesuai rasa dengan bahan baku minyak yang digunakan untuk membuat oleogel. Sedangkan cokelat F9 dan F10 menggunakan lemak CBS, walaupun diolah dari minyak sawit namun telah mengalami proses fraksinasi dan hidrogenasi dimana cokelat yang dihasilkan tidak memberikan rasa yang menyimpang dari rasa cokelat. Lemak CBS memiliki karakter fisik yang mirip dengan lemak kakao (Anonim, 2019a). 


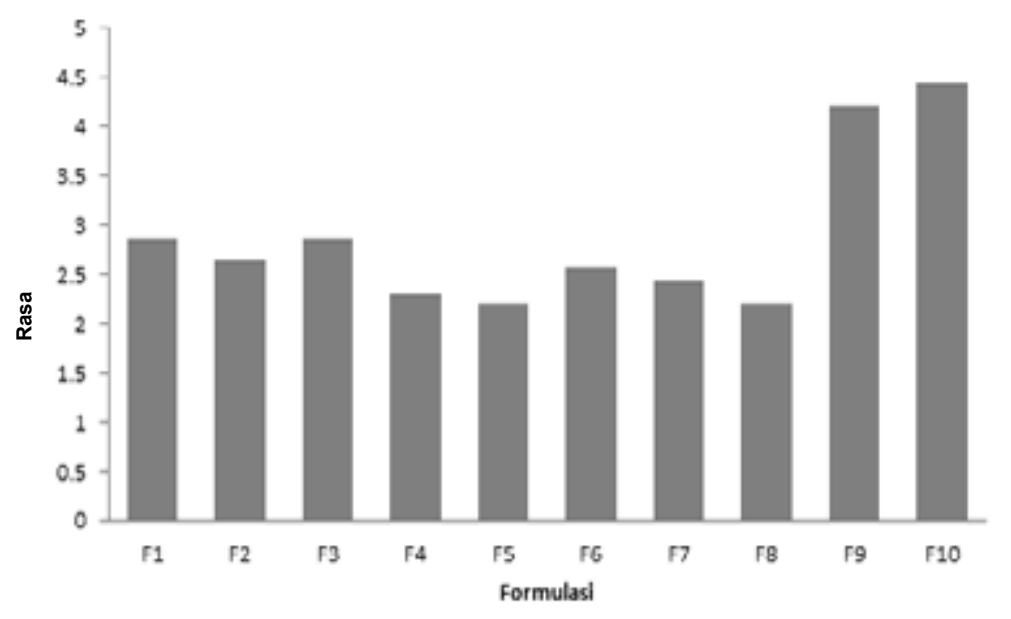

Gambar 10. Histogram Hasil Uji Organoleptik terhadap Rasa Cokelat

\section{SIMPULAN DAN SARAN}

\section{Simpulan}

Dari hasil penelitian dapat disimpulkan bahwa oleogel dari minyak sawit dan minyak kedelai dengan oleogelator lemak kakao dapat dimanfaatkan sebagai pengganti lemak pada pembuatan cokelat.

Cokelat dengan penggunaan lemak oleogel mempunyai karakteristik mutu yaitu kadar air 1,04-1,94\%, kadar gula 35,61$42,19 \%$, kadar lemak 40,01-48,25\%, kadar protein 9,64-11,03\%, kadar logam As (<0,007 ppm), Cd (<0,08 ppm), Hg (<0,003 $\mathrm{ppm})$, dan nilai rasa nilai rata-rata berkisar dari 2,21 hingga 2,86 yang berarti tidak suka hingga agak suka, kehalusan (tekstur) produk yang dihasilkan berkisar 2,21 hingga 3,29 yang berarti tidak suka hingga agak suka, warna pada produk cokelat pada formula F1 sampai F8 berkisar 3,07 hingga 3,57 yang berarti rata-rata panelis memberikan respon agak suka hingga suka, organoleptik aroma produk cokelat yang dihasilkan berkisar 2,64 hingga 3,85 yang berarti agak suka hingga suka.

\section{Saran}

Perlu penelitian lebih lanjut untuk mendapatkan oleogel yang stabil sehingga dapat mempermudah proses pengeluaran cokelat dari cetakan dan mempunyai cita rasa yang lebih baik.

\section{DAFTAR PUSTAKA}

1. Anonim, 2019a. Cocoa Butter Substitute-https://shopee.co.id/CocoaButter-Substitute-Fonta-CKSpecial-CBS-CBE-Lemak-CacaoCoklat-i.16057390.817784183 (Diakses pada 30 Oktober 2019)

2. Anonim. 2019b. Penelitian Sebut Sejumlah Merk Makanan Bayi Mengandung Logam Berat. https:// tirto.id/penelitian-sebut-sejumlahmerk-makanan-bayi-mengandunglogam-berat-dduy (Diakses pada 12 November 2019)

3. BPOM, 2018. Peraturan Badan Pengawas Obat dan Makanan No. 5 Tahun 2018. Dirjen Peraturan Perundangundangan Kementerian Hukum dan Hak Asasi Manusia Republik Indonesia

4. Buckle, K. A., Edwards, R. A., Fleet, G. H., and Wootton, M. 1987. IImu Pangan (Penerjemah Hari Purnomo dan Adiono). Penerbit Universitas Indonesia.

5. Dassanayake, L. S. K., Kodali, D. R., Ueno, S., and Sato, K. 2009. Physical Properties of Rice Bran Wax in Bulk and Organanogels. J Am. Chem. Soc. 86. 1163-73 
6. Davidovich-Pinhas, M., Barbut, S., and Marangoni, A. G. 2016. Development, Characterization and Utilization of Food-Grade Polymer Oleogels, Annu. Rev. Food Sci. Technol. Doi:10.1146/ annurev-food-041715-033225

7. deMan, M John. 1997. Kimia Makanan. Bandung: ITB

8. Iswidodo. 2010. Ini Lho Logam Berat Berbahaya bagi Tubuh. https://www.tribunnews.com/ kesehatan/2010/10/13/ini-Ihologam-berat-berbahaya-bagi-tubuh. (Diakses pada 12 November 2019)

9. Kartika.1988. Pedoman Uji Inderawi Bahan Pangan. Proyek Peningkatan/ Pengembangan Perguruan Tinggi Universitas Gadjah Mada, Yogyakarta.

10. Ketaren, S. 1986. Pengantar Minyak dan Lemak Pangan. Universitas Indonesia Press, Jakarta.

11. Kodali, D. R., 2009. The Utilization of Rice Bran Wax to Stabilize Long Chain $\omega-3$ Polyunsaturated Fatty Acid Esters. Lipid Technol. 21, 254-6

12. Meilgard, M., Civille, GV., Carr, BT. 1999. Sensory Evaluation Techniques 3rd Ed. CRC Press, Boca Raton.

13. Minifie, W., Belnard. 1999. Chocolate, Cocoa and Confectinery Sains Technology. An Aspen Publication, London.

14. Misnawi dan Jinap, S. 2008. Citarasa, Tekstur, dan Warna Cokelat dalam buku Panduan Lengkap KAKAO. Penerbit: Penebar Swadaya, Jakarta.

15. Moehyi, S. 1992. Penyelenggaran Makanan Institusi dan Jasa Boga. Bhatara. Jakarta

16. Ningsih, D. 2016. Industri Mamin Masih 100\% Andalkan Bahan Baku Impor. Artikel. http://www.beritasatu.com/ ekonomi/348025-industri-maminmasih-100-andalkan-bahan-bakuimpor.html (Diakses pada 23 Januari 2017)

17. Omron, Asia. 2016. www.omron.asia/ archive/news/2016/benefit-fromapplication-of-robotics).

18. PehlivanoĞlu, H., Demirci, M, Toker, O.S, Konar, N., Karasu, S, and Sagdic, O. 2016. Oleogels, A Promising Structured Oils for Decreasing Saturated Fatty Acid Concentrations: Production and Food-Based Applications. Critical Reviews In Food Science and Nutrition. Original Article. Manuscript accepted 10 Juli 2019

19. Prasetya, A. 2009. Komponen Pembentuk Rasa Asam pada Cokelat. http://4armita.wordpress.com. (Diakses pada 21 Juli 2019)

20. Ramlah, S. 2016. Karakteristik Mutu dan Citarasa Cokelat Kaya Polifenol. Jurnal Industri Hasil Perkebunan

21. Riadi, M. 2019. Pengertian, Sifat, Ciri dan Jenis Logam Berat. https:// www.kajianpustaka.com/2019/05/ pengertian-sifat-ciri-dan-jenislogam-berat.html. (Diakses pada 12 November 2019)

22. Ristanti, E. Y. et al. 2017. Pembuatan Oleogel dengan Menggunakan Lemak Kakao sebagai Oleogator. Laporan Penelitian, Balai Besar Industri Hasil Perkebunan, BPPI, Kementerian Perindustrian

23. Ristanti, E. Y., Yunus, M. R., Ramlah, S., Justus E. L., Sampebarra, A. L., Rejeki, E. S., Winaldi, A., Asriati, D. W., Amalia, A. N. 2018. Aplikasi Oleogel dengan Oleogator Lemak Kakao pada Produk Pangan Olahan Kakao. Laporan Penelitian. Balai Besar Industri Hasil Perkebunan. BPPI. Kementerian Perindustrian.

24. Samuditha, L., Dassanayake, K., Kodali, D. R., and Ueno, S. 2011. Current Opinion in Colloid \& Interface Science Formation of Oleogels Based On Edible Lipid Materials. Current Opinion in Colloid \& Interface Science, 16(5), 432-439. Doi:10.1016/j.cocis.2011.05.005.

25. Sugiyono. 2004. Kimia Pangan. Fakultas 
Teknik Universitas Negeri Yogyakarta. http://staff.uny.ac.id/sites/default/ files/pendidikan/ir-sugiyono-mkes/ buku-kimia-pangan.pdf. (Diakses pada 11 November 2019).

26. Supriyanto, C., Samin, Zainul, K. 2007. Analisis Cemaran Logam Berat $\mathrm{Pb}, \mathrm{Cu}$, dan $\mathrm{Cd}$ pada Ikan Air Tawar dengan Metode Spektrometri Nyala Serapan Atom (SSA). Pusat Teknologi Akselerator dan Proses Bahan, BATAN. Makalah Seminar Nasional III, SDM Teknologi Nuklir Yogyakarta, 21-22 November 2007, 147-15
27. Toro-Vazquez, JF., Morales-Rueda, JA., Dibildox-Alvarado, E., Char' o-Alonso, M., Alonzo-Macias, M., Gonz'alez-Ch'avez, MM. 2007. Thermal and Textural Properties of Organogels Developed by Candelilla Wax in Safflower Oil. J. Am. Chem. Soc. 84:989-1000

28. Van, D. 2014. Edible Applications of Shellac Oleogels: Spreads, Chocolate Paste, and Cakes. Doi:10.1039/c4fo00034j

29. Wahyudi, T., Pangabean, dan Pujiyanto. 2008. Panduan Lengkap Kakao. Penebar Swadaya, Jakarta.

30. Winarno, FG. 2004. Kimia Pangan dan Gizi. PT. Gramedia, Pustaka Utama, Jakarta. 